\title{
T cell-NF-KB activation is required for tumor control in vivo
}

\author{
Sarah E Barnes ${ }^{1}$, Ying Wang ${ }^{1}$, Luqiu Chen ${ }^{1}$, Luciana L Molinero ${ }^{3}$, Thomas F Gajewski ${ }^{1,2}$, Cesar Evaristo \\ and Maria-Luisa Alegre ${ }^{* *}$
}

\begin{abstract}
Background: $T$ cells have the capacity to eliminate tumors but the signaling pathways by which they do so are incompletely understood. T cell priming requires activation of the transcription factors AP-1, NFAT and NF-KB downstream of the TCR, but whether activation of T cell-NF-KB in vivo is required for tumor control has not been addressed. In humans and mice with progressively growing tumors, the activity of T cell-intrinsic NF-kB is often reduced. However, it is not clear if this is causal for an inability to reject transformed cells, or if it is a consequence of tumor growth. T cell-NF-kB is important for T cell survival and effector differentiation and plays an important role in enabling $T$ cells to reject cardiac and islet allografts, suggesting the possibility that it may also be required for tumor elimination. In this study, we tested whether normal T cell-NF-kB activation is necessary for the rejection of tumors whose growth is normally controlled by the immune system.
\end{abstract}

Methods: Mice with genetically impaired T cell-NF-KB activity were subcutaneously injected with MC57-SIY tumor cells. Tumor growth was measured over time, and the anti-tumor immune response was evaluated using flow cytometry and cytokine detection assays.

Results: Mice with impaired T cell-NF-KB activity were unable to reject tumors that were otherwise eliminated by wildtype mice, despite equal accumulation of tumor-reactive T cells. In addition, specific impairment of NF-KB signaling downstream of the TCR was sufficient to prevent tumor rejection. Tumor antigen-specific $T$ cell-IFN- $\gamma$ and TNF-a production, as well as cytotoxic ability, were all reduced in mice with impaired T cell-NF-kB, suggesting an important role for this transcription factor in the effector differentiation of tumor-specific effector $\mathrm{T}$ cells.

Conclusions: Our results have identified the NF-KB pathway as an important signaling axis in T cells, required for the elimination of growing tumors in vivo. Maintaining or enhancing T cell-NF-KB activity may be a promising avenue for anti-tumor immunotherapy.

Keywords: T cell, NF-KB, Tumor rejection, Priming, Effector function, Cytokine production, Cytotoxicity

\section{Background}

T cells specific for tumor antigens can play an important role in the elimination of growing tumors [1]. However, the signaling pathways elicited in T cells following tumor antigen-dependent engagement of the TCR that are required for tumor rejection are not fully understood. TCR signaling includes the activation and nuclear translocation of several transcription factors, such as nuclear factor of activated $\mathrm{T}$ cells (NFAT), activator protein-1 (AP-1) and

\footnotetext{
* Correspondence: malegre@medicine.bsd.uchicago.edu

'Department of Medicine, The University of Chicago, 924 E. 57th St.

JFK-R312, Chicago, IL 60637, USA

Full list of author information is available at the end of the article
}

nuclear factor- $\mathrm{k}$-light chain enhancer of activated $\mathrm{B}$ cells (NF-kB) [2]. However, ablation of NFAT1 from $\mathrm{T}$ cells results in improved rather than impaired tumor control, underscoring the importance of NFAT1 in T cell anergy [3]. Nevertheless, while targeted disruption of NFAT1 or NFAT2 genes separately did not prevent T cell activation and IL-2 production, expression of a dominant negative NFAT in T cells did [4], suggesting that complete elimination of NFAT activity may prevent tumor control in vivo, although this has not been tested directly. Similarly, mice with genetic ablation selectively in T cells of c-Fos, an AP-1 subunit, displayed better, rather than worse, tumor control while mice with transgenic expression of 
c-Fos in $\mathrm{T}$ cells conversely experienced accelerated tumor growth [5]. In this case, the immunosuppressive effect of c-Fos was due to the induction in T cells of the negative regulator programmed death-1 (PD-1), a direct target of AP-1. As with NFAT, complete ablation of the AP-1 subunits might be expected to prevent tumor rejection. The functional role of the third main transcription factor of $\mathrm{T}$ cell activation, NF- $\mathrm{kB}$, in tumor control remains to be determined.

Factors produced by tumors can directly or indirectly inhibit TCR-induced NF- $\mathrm{kB}$ activation, as shown with $\mathrm{T}$ cells isolated from patients with renal cell carcinoma [6], non-small cell lung cancer [7], or exposed to ascites fluid from an ovarian cancer patient [8]. Similarly, mice with growing tumors can harbor reduced NF- $\mathrm{KB}$ activity in peripheral $\mathrm{T}$ cells $[9,10]$. However, whether a reduction in $\mathrm{T}$ cell-NF- $\kappa \mathrm{B}$ activity can be a cause for why $\mathrm{T}$ cells fail to control tumor growth and not just a consequence of tumor expansion, or whether other transcription factors can compensate in vivo for deficient NF-kB activity, remains to be tested. Understanding the signaling pathways that contribute to tumor rejection when it is successful may help design therapies to promote tumor elimination when it is not spontaneously achieved.

The transcription factor NF- $\mathrm{kB}$ comprises a family of proteins that include DNA binders (p50, p52) and DNA transactivators (RelA, RelB and c-Rel) [11]. In the absence of a stimulus, heterodimers of these subunits are retained in the cytoplasm by inhibitors of NF-kB (IKB). TCR activation results in the phosphorylation of the lipid raft-associated CAspase Recruitment domain MembraneAssociated guanylate kinase protein 1 (CARMA1) [12]. Phosphorylated CARMA1 associates with the protein B cell lymphoma 10 (Bcl-10), which acts as a scaffold for the mucosa-associated lymphoid tissue lymphoma translocation gene-1 (MALT1). The complex formed by CARMA1, Bcl-10, and MALT1 induces the activation of the IкB kinase complex IKK (IKK $\alpha$, IKK $\beta$ and NEMO), which then phosphorylates ІкB, an event that targets ІкB for K48 ubiquitination and degradation by the $26 \mathrm{~S}$ proteasome. This uncovers a nuclear localization domain within NF- $\mathrm{KB}$ dimers that enables them to translocate into the nucleus and initiate gene transcription.

Several genetic mouse models of NF- $k B$ impairment in $\mathrm{T}$ cells have been generated, including the transgenic expression selectively in $\mathrm{T}$ cells of a mutated form of I $\mathrm{I} B \alpha$ that cannot be degraded (I $\mathrm{KB} \alpha \Delta \mathrm{N}-\mathrm{Tg}$ mice) [13], the conditional deletion of IKK $\beta$ (CD4-cre $x \operatorname{IKK} \beta^{\mathrm{fl} / \mathrm{fl}}$ mice) [14] and the elimination of CARMA1 expression (CARMA1-KO mice) [15-17]. T cells from the first 2 strains have impaired NF- $\mathrm{kB}$ activation not only downstream of the TCR, but also of other receptors that activate NF-kB in T cells, such as tumor necrosis factor receptor (TNFR) family members and Toll-like receptor
(TLR) family members. In contrast, TCR-dependent but not TNFR- or TLR-dependent NF- $\mathrm{kB}$ signaling is absent in CARMA1-KO T cells. Using these mice, our group and others have shown that $\mathrm{T}$ cell-NF- $\mathrm{kB}$ plays a role in the proliferation and survival of $\mathrm{T}$ cells. Because of its requirement in cell-cycle progression, $\mathrm{T}$ cell-NF- $\kappa \mathrm{B}$ is important for Th1 and Th17 differentiation; however, if proliferation is rescued, Th1 differentiation can proceed whereas $\mathrm{T}$ cell-NF- $\mathrm{kB}$ controls Th17 differentiation at an additional downstream checkpoint, by enabling accessibility of the IL-17 locus [18-22]. Whereas T cell NF- $\kappa B$ is required for the thymic development of natural Tregs [23-27], and c-Rel can play a modest role in the differentiation of peripherally induced Tregs (iTregs) [25-27], T cell-NF-kB can antagonize iTreg differentiation when strongly induced at high antigen doses [28]. In vivo, the role of T cell-NF- $\mathrm{KB}$ has proven complex. For instance, its importance in the rejection of transplanted organs was dependent on the tissue origin of the graft. While IкB $\alpha \Delta \mathrm{N}-\mathrm{Tg}$ and CARMA1-KO mice failed to reject fully mismatched cardiac allografts and displayed delayed rejection of islet allografts, they successfully rejected skin allografts with only slightly delayed kinetics [21,29,30]. Given these pleiotropic and complex functions of T cell-NF- $\mathrm{kB}$, its role in tumor control cannot be easily anticipated.

In the current study, we investigated whether normal activation of NF- $\mathrm{KB}$ in $\mathrm{T}$ cells is required for the rejection of tumors that are normally controlled by wildtype mice. Because I $\mathrm{k} \alpha \alpha \mathrm{N}-\mathrm{Tg}$ mice have defects in thymic selection resulting in reduced numbers of thymic and peripheral $T$ cells perhaps due to the early expression of the transgene driven by the Lck promoter, CD4-cre $\mathrm{x} I K K \beta^{\mathrm{fl} / \mathrm{fl}}$ and CARMA1-KO mice were employed to address this question, as they have closer to normal numbers of $\mathrm{CD} 4^{+}$and $\mathrm{CD}^{+}$conventional $\mathrm{T}$ cells. We found that mice with impaired $\mathrm{T}$ cell-NF- $\mathrm{kB}$ activity were unable to reject tumors that were otherwise eliminated by wildtype mice, and specific impairment of NF- $\mathrm{kB}$ signaling downstream of the TCR was sufficient to preclude anti-tumor responses. Reduced $\mathrm{T}$ cell-NF- $\mathrm{kB}$ activity did not reduce expansion of tumor-specific $\mathrm{T}$ cells, but resulted in decreased production of tumor antigen-specific IFN- $\gamma$ and TNF- $\alpha$, as well as diminished cytotoxicity against tumor antigen-expressing cells in vivo. Thus, T cell-NF- $\kappa \mathrm{B}$ is required for the successful elimination of tumors. Our data identify this signaling pathway as a potential therapeutic target to enhance anti-tumor immunity in cancer patients.

\section{Results}

\section{Rejection of MC57-SIY is dependent on T cell-IKK $\beta$}

To determine whether $\mathrm{T}$ cell-NF- $\mathrm{kB}$ signaling was required for tumor rejection, we examined the ability of $\mathrm{T}$ cell-NF$\kappa \mathrm{B}$-impaired mice to reject a transplantable tumor. To this 
end, we utilized CD4-cre $x \operatorname{IKK} \beta^{\mathrm{t} / \mathrm{fl}}$ mice, the $\mathrm{T}$ cells from which lack the kinase IKK $\beta$ that is required for the phosphorylation of I $\mathrm{B}$ and consequent nuclear translocation of NF- $\mathrm{KB}$ molecules. In these mice, cre-mediated deletion of IKK $\beta$ occurs at the double positive stage of thymocyte development, resulting in absence of IKK $\beta$ from all peripheral $\mathrm{CD} 4^{+}$and $\mathrm{CD} 8^{+} \alpha \beta$ T cells. CD4-cre $\mathrm{x} \operatorname{IKK} \beta^{\mathrm{fl} / \mathrm{fl}}$ mice have been previously described [14,31], and their $\mathrm{T}$ cells displayed normal survival and activation by polyclonal stimuli in vitro, expanded efficiently in response to superantigen administration in vivo, but were deficient in recall responses, help for germinal center formation, and lymphopenia-induced homeostatic proliferation $[31,32]$. CD4-cre $x \quad I K K \beta^{\mathrm{fl} / \mathrm{fl}}$ mice and littermate controls $\left(\mathrm{CD} 4\right.$-cre $\mathrm{x} I \mathrm{IKK} \beta^{+/ f l}$ ) were subcutaneously injected with $10^{6}$ MC57-SIY tumor cells, a mouse fibrosarcoma cell line engineered to express the model peptide antigen SIYRYYGL (SIY). This transplantable tumor is spontaneously rejected by wildtype mice [33]. While littermate controls successfully rejected the MC57-SIY tumors, CD4-cre $\mathrm{x}$ $\operatorname{IKK} \beta^{\mathrm{I} / / \mathrm{l}}$ mice did not (Figure 1a). To determine if this was due to an inability of CD4-cre $x \operatorname{IKK} \beta^{\mathrm{f} / \mathrm{fl}}$ mice to mount any kind of immune response when antigens were present in a cutaneous location, we examined whether they could reject skin grafts. CD4-cre $\mathrm{x} \mathrm{IKK} \beta^{\mathrm{f} / \mathrm{fl}}$ mice $(\mathrm{C} 57 \mathrm{BL} / 6$ background, $\mathrm{H}-2^{\mathrm{b}}$ ) successfully rejected a fully mismatched $\mathrm{BALB} / \mathrm{c}\left(\mathrm{H}-2^{\mathrm{d}}\right)$ skin allograft, albeit with slower kinetics than wildtype mice (Figure $1 \mathrm{~b}$ ). Therefore, T cell-IKK $\beta$ was necessary for elimination of MC57-SIY tumors but was not required for the complete destruction of skin allografts.

\section{Initial T cell priming is unimpaired in CD4-cre $x \operatorname{IKK} \beta^{\mathrm{fl} / f 1}$ mice}

Lack of tumor rejection in CD4-cre $\mathrm{x} I K K \beta^{\mathrm{fl} / \mathrm{fl}}$ mice may depend on impaired survival, proliferation, differentiation, migration or effector function of tumor-reactive $\mathrm{T}$ cells in vivo. To investigate the fate of anti-tumor $\mathrm{T}$ cells, we used fluorescently labeled pentamers of the MHC class I $\mathrm{K}^{\mathrm{b}}$ molecule coupled to the SIY peptide to identify
SIY-reactive T cells. Mice inoculated with MC57-SIY tumor cells were sacrificed on day 7 , which was determined to be the height of the anti-tumor response [33], and splenocytes were analyzed by flow cytometry. Frequencies (Figure 2a) and absolute numbers (Figure $2 \mathrm{~b}$ ) of SIY-specific $\mathrm{T}$ cells were similar between CD4-cre $x$ IKK $\beta^{\mathrm{fl} / \mathrm{fl}}$ mice and littermate controls, suggesting similar expansion and survival of SIY-specific $\mathrm{CD}^{+} \mathrm{T}$ cells following tumor exposure regardless of the presence or absence of IKK $\beta$.

Because SIY is a model antigen, we also compared the proliferation of all activated $\mathrm{CD} 8^{+} \mathrm{T}$ cells that should also contain $\mathrm{T}$ cells reactive to non-SIY tumor antigens as well as tumor non-specific $\mathrm{T}$ cells. Splenocytes isolated 7 days following tumor inoculation were gated on $\mathrm{CD} 8^{+} \mathrm{CD} 44^{\text {hi }}$ populations and expression of Ki67, a nuclear protein induced during the active phases of the cell cycle, was assessed. As shown in Figures 2c and $2 \mathrm{~d}$, the proportion and total number of proliferating $\mathrm{CD}^{+} \mathrm{T}$ cells increased similarly following tumor injection in control and CD4-cre $\mathrm{x} \mathrm{IKK} \beta^{\mathrm{fl} / \mathrm{fl}} \mathrm{T}$ cells, indicating that the initial $\mathrm{T}$ cell priming and cell survival following tumor implantation occurred normally despite lack of $\mathrm{T}$ cell-IKK $\beta$.

\section{T cell-IKK $\beta$ is required for anti-tumor effector function}

To determine if a differentiation step downstream of $\mathrm{T}$ cell proliferation was affected by lack of IKK $\beta$, IFN- $\gamma$ production upon tumor antigen re-challenge in vitro was measured by ELISpot in splenocytes harvested 7 days post-tumor injection. Fewer CD4-cre $\mathrm{x} I K K \beta^{\mathrm{fl} / \mathrm{fl}}$ than wildtype splenocytes secreted IFN- $\gamma$ upon restimulation with irradiated MC57-SIY tumor cells (Figure 3a). Additionally, the production of IFN- $\gamma$ from CD4-cre $x$ $\mathrm{IKK} \beta^{\mathrm{fl} / \mathrm{fl}}$ mice was reduced on a per-cell basis compared to littermate controls, as assessed by mean ELISpot size (Figure 3b).

Because cells other than T cells can produce IFN- $\gamma$, and to determine if $\mathrm{CD}^{+} \mathrm{T}$ cells specifically had impaired cytokine production in CD4-cre $\mathrm{x} I K K \beta^{\mathrm{fl} / \mathrm{ll}}$ tumor-bearing
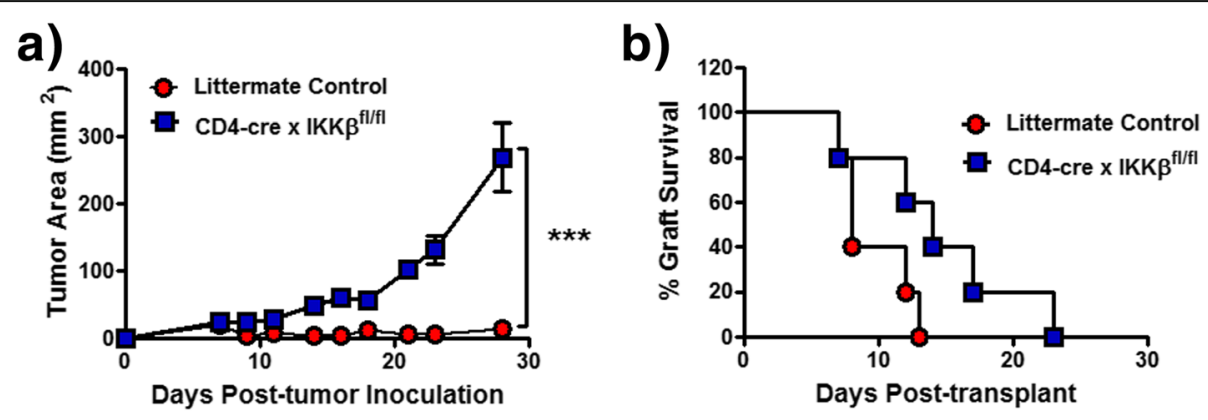

Figure 1 IKK $\beta$ expression in T cells is required for MC57-SIY tumor rejection. a) One million MC57-SIY tumor cells were subcutaneously injected into CD4-cre $\times 1 K K \beta^{f l / f l}$ mice, and tumor growth was measured over time. b) Fully mismatched skin from wildtype BALB/C mice $\left(H-2^{d}\right)$ was transplanted into $\mathrm{CD} 4-\mathrm{cre} \times \mathrm{IKK} \beta^{\mathrm{fl} / \mathrm{fl}}$ mice $\left(\mathrm{H}-2^{\mathrm{b}}\right)$. Results are representative of at least 2 experiments. ${ }^{* * *} \mathrm{p}<0.001$. 


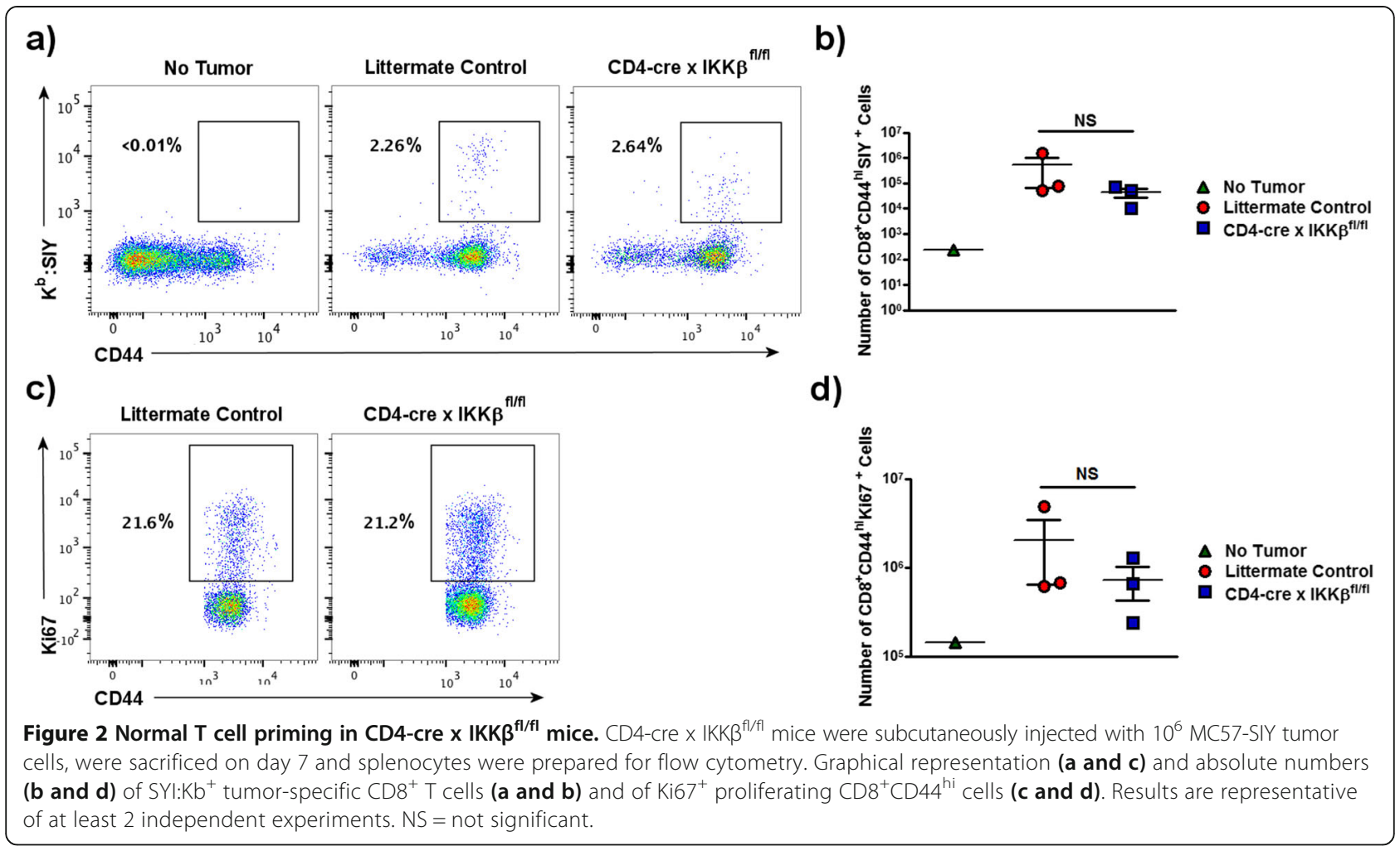

mice, $\mathrm{CD} 8^{+} \mathrm{T}$ cells were enriched from the spleen on day 7 post-tumor implantation using magnetic bead-based negative selection, and restimulated with irradiated tumor cells or PMA + ionomycin. Cytokine secretion was assessed using a cytokine bead array. $\mathrm{CD} 8^{+} \mathrm{T}$ cells from CD4-cre $x \operatorname{IKK} \beta^{\mathrm{fl} / \mathrm{fl}}$ mice had dramatically reduced IFN- $\gamma$ and TNF- $\alpha$ production in response to tumor cell restimulation (Figure 3c). Surprisingly, these cells retained the ability to produce IFN- $\gamma$ and TNF- $\alpha$ in response to PMA and ionomycin (Figure $3 \mathrm{c}$ and see Additional file 1: Figure S1), a combination of stimuli that bypasses the TCR and also stimulates the diversity of $\mathrm{CD}^{+} \mathrm{T}$ cells present in the culture. These findings suggest either that activated $\mathrm{T}$ cells were specifically unresponsive to tumor antigens upon re-challenge, or that they had failed to differentiate into IFN- $\gamma$ - or TNF- $\alpha$-producing cells in response to the tumor in vivo.

To further examine the extent of the functional deficiency in IKK $\beta$-deficient tumor-specific T cells, we performed an in vivo cytotoxicity assay. CD4-cre $\mathrm{x}$ $\mathrm{IKK} \beta^{\mathrm{fl} / \mathrm{fl}}$ mice and control littermates were injected with MC57-SIY tumor cells, and on day 7 post-inoculation, a 1:1 ratio of CFSE-labeled $\mathrm{T}$ cell-depleted splenocytes loaded with SIY tumor antigen (exposed to low CFSE concentration) versus left unloaded (exposed to high CFSE concentration) was transferred intravenously into each mouse. Mice were sacrificed 18 hours later and specific target lysis was calculated using the ratio of the two transferred populations evaluated by flow cytometry (Figure 3d). Compared to wildtype littermate controls, CD4-cre $x \operatorname{IKK} \beta^{\mathrm{fl} / \mathrm{fl}}$ tumor-bearing mice demonstrated a very significant reduction in specific lysis (Figure 3e). Taken together, these findings suggest that, while other factors may contribute to the survival and proliferation of $\mathrm{T}$ cells, IKK $\beta$ expression is required to enable effector function during the anti-tumor immune response.

\section{Rejection of the MC57-SIY tumor is dependent on NF-кB signaling downstream of the $\mathrm{T}$ cell receptor}

NF- $\mathrm{KB}$ in T cells can be activated by IKK $\beta$ downstream of several receptors, including TLRs, members of the TNFR superfamily, and the TCR. To assess whether T cell-IKK $\beta$ requirement for tumor rejection was due to TLR-dependent NF- $\mathrm{kB}$ activation as TLRs may detect damage-associated molecular patterns released during tumorigenesis, tumor rejection in MyD88-KO mice was analyzed. MyD88 is an adaptor downstream of most TLRs and necessary for TLRs to activate NF- $\mathrm{kB}$ [34]. MC57-SIY tumor cells were injected into MyD88-KO mice and wildtype controls both on the C57BL/6 background, and tumor growth was measured over time. Both MyD88-KO and wildtype mice rejected the tumors (Figure 4a), indicating that TLR-dependent NF- $\kappa B$ signaling is not required for the rejection of MC57-SIY tumors. 


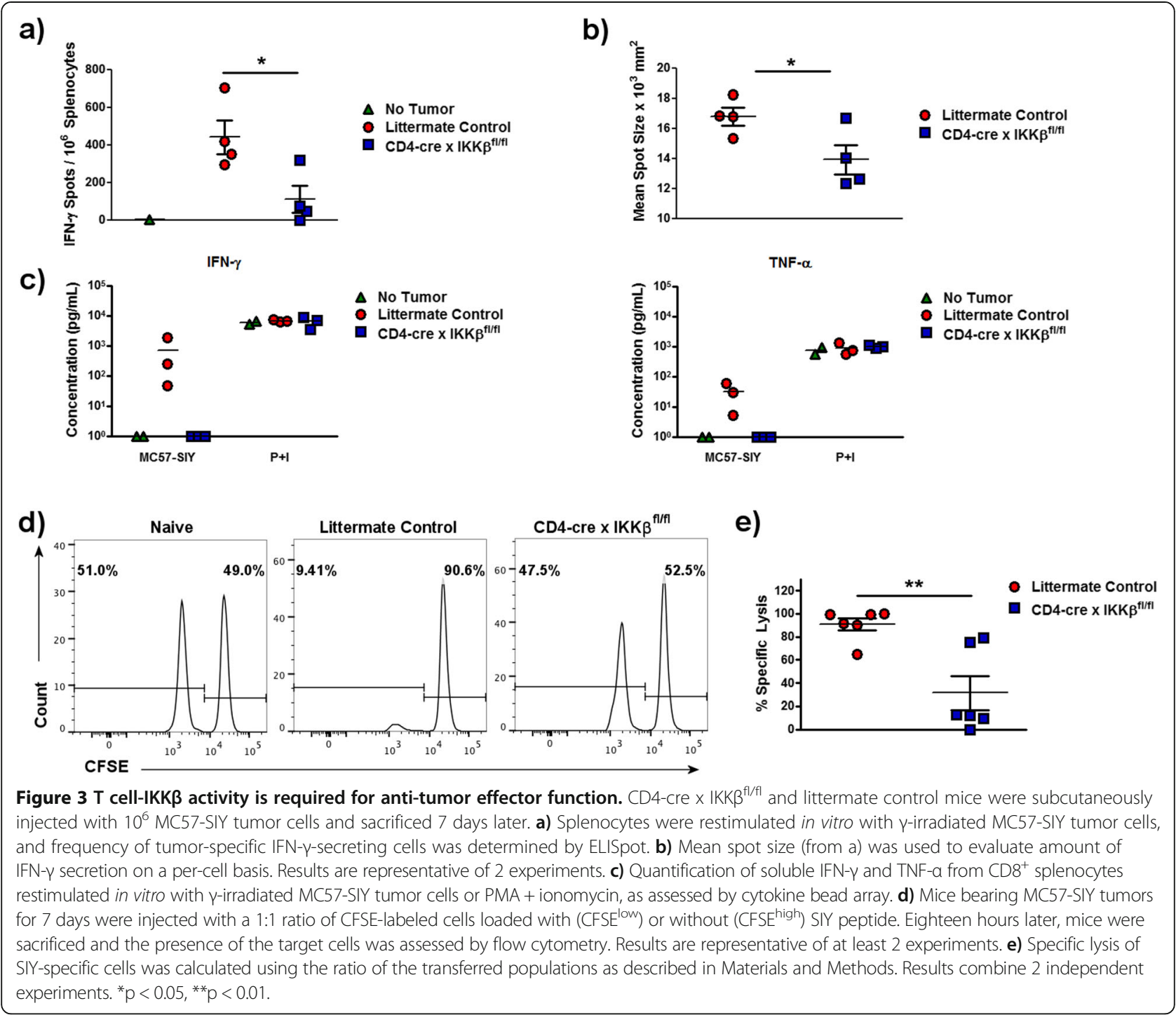

To address whether NF-kB signaling specifically downstream of the TCR was required for tumor rejection, tumor growth was analyzed in CARMA1-KO mice that lack the key adaptor connecting the TCR to the NF-kB activating machinery. Whereas wildtype mice successfully rejected the tumors, CARMA1-KO mice failed to prevent growth of MC57-SIY tumors (Figure 4b). As observed for CD4-cre $x$ $\operatorname{IKK} \beta^{\mathrm{f} / \mathrm{fl}}$ mice, this was not due to a complete failure of CARMA1-KO mice to mount any immune response in vivo, as we have previously shown that they successfully reject fully allogeneic BALB/c skin grafts [21]. Similarly to CD4-cre $x \operatorname{IKK} \beta^{\mathrm{f} / \mathrm{fl}}$ mice, enriched $\mathrm{CD} 8^{+}$splenic $\mathrm{T}$ cells from tumor-bearing CARMA1-KO mice failed to produce IFN- $\gamma$ in response to re-stimulation with irradiated tumor cells (Figure 4c), indicating a failure to mount a successful anti-tumor effector response. Taken together, these findings indicate that NF- $\mathrm{kB}$ activation downstream of the TCR is required for the elimination of MC57-SIY tumors.

\section{Discussion}

NF- $\mathrm{kB}$ is activated in many cancer types and has also been associated with angiogenesis, tumor progression and metastasis [35]. For instance, we have shown that the development of acute $\mathrm{T}$ cell lymphoplastic leukemia driven by Notch-1 in mice depends on the ability of Notch to activate the NF- $k B$ pathway [36]. Recently, $\mathrm{NF}-\mathrm{\kappa B}$ in parenchymal tumor cells was also shown to promote $\mathrm{T}$ cell recruitment in mice and humans [37]. However, the role of NF- $\mathrm{kB}$ within non-transformed T cells in their ability to control growth of parenchymal cancers had not been previously investigated. Our data show that both CD4-cre $x \operatorname{IKK} \beta^{\mathrm{fl} / \mathrm{fl}}$ and CARMA1-KO mice fail to reject tumors that are otherwise eliminated by wildtype mice. Although the results point to the importance of T cell-NF- $\mathrm{KB}$ in tumor rejection, we cannot rule out that other signaling pathways downstream of IKK $\beta$ or CARMA1 may play a role in addition to, or instead of, 


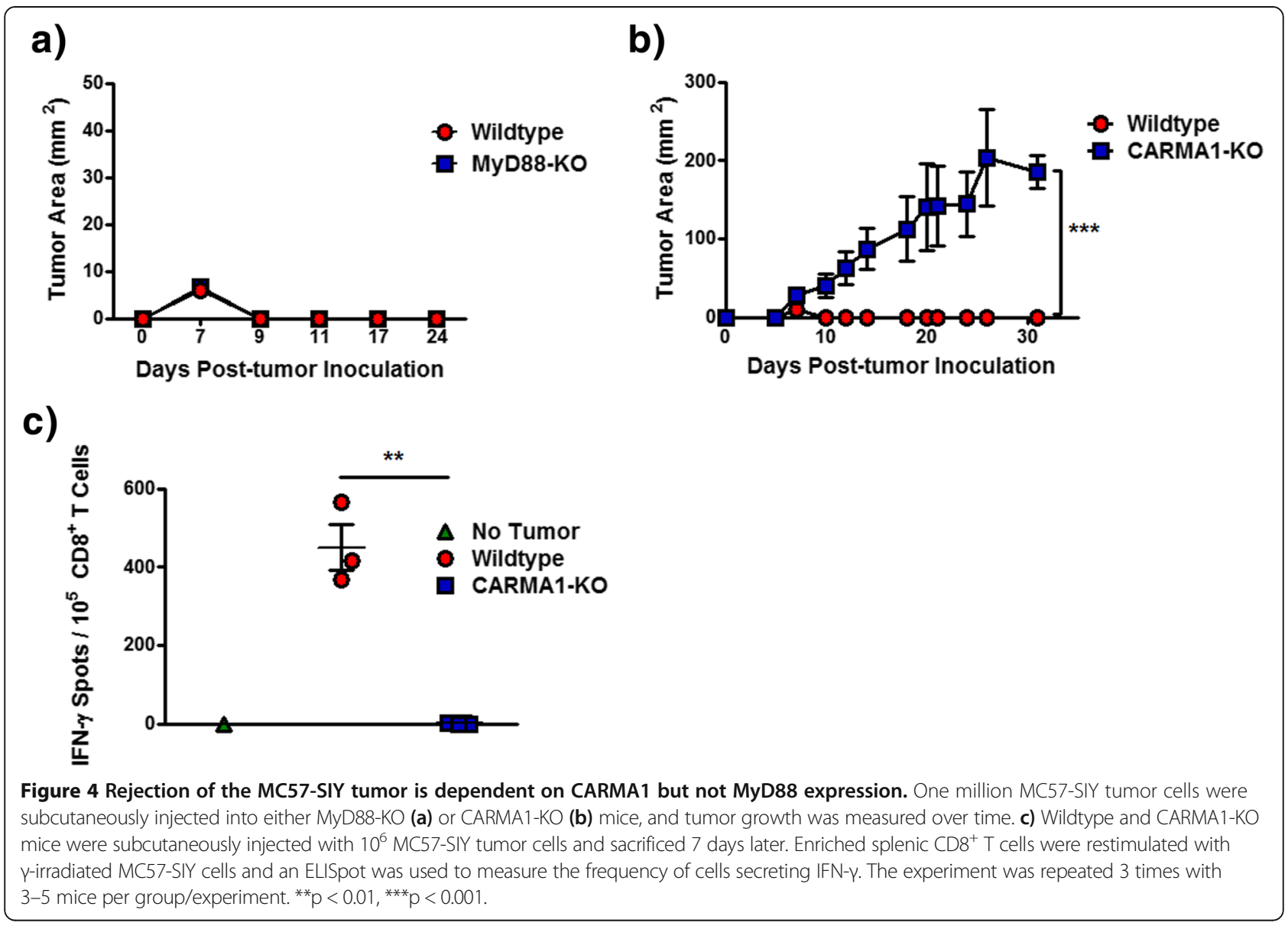

NF-kB. Indeed, IKK $\beta$ has been shown to phosphorylate other substrates than I $\mathrm{KB}$, including the Forkhead transcription factor FOXO3a, the mRNA destabilizer 14-3-3b, the insulin receptor substrate 1 and the docking protein 1 [38]. Similarly, CARMA1 has been shown to activate JNK2 in addition to NF- $\mathrm{BB}$ [39]. However, preliminary results indicate that ІкB $\alpha \mathrm{N}-\mathrm{Tg}$ mice, in which $\mathrm{T}$ cells express a transgenic super-repressor form of IкB $\alpha$, also have a defect in controlling MC57-SIY tumor growth (data not shown). The convergence of this same phenotype in 3 different genetic models, the common intersecting point being $\mathrm{T}$ cell-NF- $\mathrm{kB}$ impairment, strongly supports the hypothesis that normal activation of $\mathrm{NF}-\mathrm{kB}$ in T cells is essential for tumor control in vivo. Moreover, other signaling pathways downstream of the TCR, such as NFAT or AP-1, cannot compensate for the absence of $\mathrm{T}$ cell-NF-kB. The tumor-controlling role of $\mathrm{T}$ cell-NF- $\kappa B$ suggests that augmenting the signaling of NF- $\mathrm{kB}$ may facilitate tumor rejection.

Although T cell-NF- $k B$ has been implicated by us and by others in the survival and proliferation of conventional $T$ cells in other model systems, our current results indicate that tumor-specific CD4-cre $\mathrm{x} I K K \beta^{\mathrm{fl} / \mathrm{fl}} \mathrm{CD} 8^{+} \mathrm{T}$ cells were able to expand and accumulate in tumor-bearing mice.
Thus, other signaling pathways may be sufficient to support $\mathrm{T}$ cell proliferation and expansion in the absence of IKK $\beta$ in vivo. For instance, IKK $\alpha$ and IKK $\beta$ can substitute for one another for thymocyte development [40]. In addition, the lack of a defect in IKK $\beta$-deficient $\mathrm{T}$ cell survival and proliferation in this tumor model allowed us to probe the role of NF- $\mathrm{kB}$ downstream of these early $\mathrm{T}$ cell priming events and identify an essential role for IKK $\beta$ in the acquisition of IFN- $\gamma$ and TNF- $\alpha$ production by tumor-specific $\mathrm{CD}^{+} \mathrm{T}$ cells as well as of cytotoxicity in vivo. This observation is consistent with reports indicating that an NF- $\mathrm{kB}$-binding site controls granzyme $B$ transcription and that the $c-$ Rel subunit of NF- $\mathrm{KB}$ (but not the p50 subunit) can bind to enhancer sites on the IFN- $\gamma$ gene $[41,42]$. This impaired effector response is likely one of the mechanisms by which CD4-cre $x \operatorname{IKK} \beta^{\mathrm{fl} / \mathrm{fl}}$ mice fail to reject MC57-SIY tumors, as T cell-IFN- $\gamma$ and cytotoxicity are functions known to play important roles in the rejection of various growing tumors [43-45]. The fact that $\mathrm{CD}^{+} \mathrm{T}$ cells from CD4-cre $\times I_{K K} \beta^{\mathrm{f} / \mathrm{fl}}$ tumor-bearing mice could produce IFN- $\gamma$ in response to PMA/ionomycin suggests that tumor-specific IKK $\beta$-deficient $\mathrm{T}$ cells may be anergic or hyporesponsive despite their initial proliferation, as 
anergic $\mathrm{T}$ cells have defects in Ras signaling which can be functionally rescued by bypassing early steps of $\mathrm{T}$ cell activation [46]. Alternatively, PMA/ionomycin may be eliciting IFN- $\gamma$ from previously differentiated non tumor-reactive $T$ cells, suggesting that IKK $\beta$ may be dispensable for effector differentiation in certain settings. It is conceivable that exposure of mice prior to tumor inoculation to environmental antigens in the presence of particular signals such as from pattern-recognition receptors, costimulatory molecules, or inflammatory cytokines may have enabled differentiation of a subset of $\mathrm{T}$ cells in the absence of IKK $\beta$. Of note, while the expansion of CD4-cre $\mathrm{xIKK} \beta^{\mathrm{fl} / \mathrm{fl}} \mathrm{CD} 8^{+} \mathrm{T}$ cells was preserved in our studies, these cells displayed reduced binding to $\mathrm{K}^{\mathrm{b}}: \mathrm{SIY}$ fluorescent pentamers (see Figure 2a), perhaps reflecting loss of high avidity clones. Indeed, varying TCR:ligand affinity in TCR $\beta$ mutant mice has been correlated with differential NF- $\mathrm{kB}$ activation and distinct $\mathrm{CD}^{+} \mathrm{T}$ cell fate decisions [47]. Thus, tumor immune responses in mice with impaired $\mathrm{T}$ cell-NF- $\mathrm{KB}$ may be limited because of deletion or lack of expansion of clones with high affinity for tumor antigens.

$\mathrm{T}$ cell-NF- $\mathrm{kB}$ is differently required for the elimination of distinct tissues in vivo, as it is essential for the rejection of cardiac but not skin allografts, although the tempo of skin rejection is slower than in control mice $[29,48]$. The fate of MC57-SIY tumors appears to segregate with that of cardiac rather than skin allografts, despite the tumors being positioned in a similar location as the skin graft bed. The underlying mechanisms for the differential role of $\mathrm{T}$ cell-NF- $\mathrm{kB}$ in the rejection of the various tissues are incompletely understood, but several factors likely play a role in providing sufficient signal strength to enable $\mathrm{T}$ cell activation despite reduced NF- $\kappa B$. These may include differences in antigen load, site and quality of initial $\mathrm{T}$ cell priming and types of APCs present in the different tissues. For instance, we have previously shown that skin Langerhans cells but not splenic dendritic cells can activate NF- $\kappa B$-impaired T cells and that transfer of donor-matched Langerhans cells is sufficient to drive rejection of cardiac allografts in $\mathrm{T}$ cell-NF- $\kappa \mathrm{B}$-impaired mice [49]. Whether absence of tumor control in mice with impaired T cell-NF- $\kappa B$ is due to these tumors lacking potent immune-stimulatory APCs remains to be demonstrated, but is consistent with the reduced $\mathrm{T}$ cell effector function observed in these mice.

$\mathrm{NF}-\mathrm{KB}$ in $\mathrm{T}$ cells can be activated downstream of several surface receptors, including the TCR, most TLRs, and all TNFR family members [50]. The fact that CARMA1-KO but not MyD88-KO mice fail to reject MC57-SIY tumors suggest that TCR-NF-kB but not TLR-NF- $\kappa B$ plays a role in tumor control. TNFR family members are mostly expressed on activated rather than naïve $T$ cells and include HVEM, CD27, CD30, $\mathrm{OX} 40$ and 4-1BB [51]. Engagement of these receptors by their respective soluble or membrane-bound ligands serves to costimulate activated $\mathrm{T}$ cells and results in TRAF-dependent activation of NF-kB [51-53], which is prevented by lack of expression of IKK $\beta$ but not of CARMA1. Whether NF- $\mathrm{kB}$ activity downstream of TNFR family members also plays a role in $\mathrm{T}$ cell-mediated spontaneous control of tumor growth remains to be investigated. Agonistic antibodies to 4-1BB, OX40 and CD27 that are immune-stimulatory are being tested as potential immunotherapies for cancer patients and the efficacy of anti-4-1BB pre-clinically has been shown to depend on TRAF2-mediated NF-kB activation [54].

Our data suggest that $\mathrm{T}$ cell-NF- $\mathrm{kB}$ is essential for the spontaneous rejection of transplantable tumors. It remains to be tested if it also plays a role in tumor surveillance and elimination of nascent autochthonous tumors. CD4-cre $\mathrm{x} I K K \beta^{\mathrm{fl} / \mathrm{fl}}$ or CARMA1-KO mice do not appear to develop spontaneous tumors as they age, but this may be because the animals are kept in specific pathogen-free facilities and are not exposed to oncogeneic viruses or environmental carcinogens which may be necessary to drive tumor initiation [55]. Whether inhibition of $\mathrm{T}$ cell-NF- $\mathrm{kB}$ accelerates the development of spontaneous genetic or carcinogen-induced tumors, or prevents the efficacy of current immunotherapies such as blockade of the CTLA-4/B7 or PD-1/PDL1 pathways will be of interest to study in the future. In particular, we have previously shown that CTLA-4 and PD-1 inhibit TCR-mediated NF- $\mathrm{kB}$ activity $[56,57]$ such that their blockade in vivo may conceivably function through enhancement of NF-kB signaling.

\section{Conclusions}

$\mathrm{T}$ cell-NF- $\mathrm{kB}$ plays an important role in tumor control, indicating that reduced T cell-NF- $\mathrm{kB}$ observed in tumorbearing hosts can be a cause of tumor progression and that other transcription factors cannot compensate in vivo for deficient NF-kB activity in T cells. These data suggest that enhancing this axis either genetically or with immunotherapies such as agonistic antibodies against TNFR family members are important therapeutic considerations. Based on our findings, we propose that the maintenance of NF- $\mathrm{kB}$ activity in T cells could facilitate tumor rejection by supporting $\mathrm{T}$ cell effector function, specifically pro-inflammatory cytokine secretion and specific cytotoxicity. It will be important to design such therapies to target only $\mathrm{T}$ cells, as enhancing NF- $\mathrm{kB}$ in cancer cells could contribute to tumor progression.

\section{Methods}

\section{Animal models}

C57BL/6 and BALB/c mice were obtained from Harlan Laboratories (Indianapolis, IN). CD4-cre mice, purchased from Jackson Laboratories [017336; B6.Cg- $\mathrm{Tg}(\mathrm{Cd} 4-$ 
cre) $1 \mathrm{Cwi} / \mathrm{Bflu}]$ ], express the cre recombinase under the control of the $\mathrm{CD} 4$ promoter and have been previously described $[58,59]$. IKK $\beta^{\mathrm{t} / \mathrm{fl}}$ mice, which express a loxPflanked IKK $\beta$ locus and have been previously described [60], were generously provided by Dr. Michael Karin (University of California San Diego, San Diego, CA). CD4-cre mice were crossed with $I K K \beta^{\mathrm{fl} / \mathrm{fl}}$ mice in house (CD4-cre $x I K K \beta^{\mathrm{fl} / \mathrm{fl}}$ mice). CARMA1-KO mice were originally generated on the 129 background [16], were a gift from Dr. Daniel Littman (New York University, New York, NY) and were backcrossed for 6-10 generations onto the C57BL/6 background at the University of Chicago specific pathogen-free (SPF) barrier facility. MyD88-KO mice are deficient in the adaptor molecule MyD88 in all tissues [61] and were a gift from Dr. Alexander Chervonsky (University of Chicago, Chicago, IL). All mice were on the C57BL/6 background and bred at the University of Chicago SPF facility in agreement with our Institutional Animal Care and Use Committee (IACUC) and according to the National Institutes of Health guidelines for animal use.

\section{Tumor cell lines}

The MC57 methylcholanthrene-induced fibrosarcoma cell line was provided by Dr. Hans Schreiber (University of Chicago, Chicago, IL). MC57-SIY was engineered to express the model antigen SIYRYYGL, which can be recognized by $\mathrm{CD}^{+} \mathrm{T}$ cells in the context of $\mathrm{H} 2-\mathrm{K}^{\mathrm{b}}$ [33].

\section{Tumor challenge and measurement}

Tumor cells were washed and resuspended in PBS at a concentration of $10^{7}$ cells $/ \mathrm{mL}$. A volume of $0.1 \mathrm{~mL}$ ( $10^{6}$ tumor cells) was injected subcutaneously into the right flank of each mouse. Tumors were measured with calipers by a single investigator, and tumor size was calculated as the product of the greatest tumor diameter length and its perpendicular width.

\section{Skin transplantation}

The tail skin of euthanized BALB/c $\left(\mathrm{H}-2^{\mathrm{d}}\right)$ donor mice was cleaned with $70 \%$ ethanol. $1 \times 1 \mathrm{~cm}$ segments of skin were removed with sterile scissors and attached onto a Petri dish maintained at $4^{\circ} \mathrm{C}$, where they were kept moist with a sterile gauze soaked in $0.9 \% \mathrm{NaCl}$. C57BL/6 $\left(\mathrm{H}-2^{\mathrm{b}}\right)$ recipient mice were anesthetized with ketamine/xylazine. The surgical site was shaved and disinfected with povidone-iodine. Using sterile curved scissors, an area of flank skin was removed. The donor skin graft was placed onto the prepared graft bed, and secured with two Bandaids. After 7 days, the adhesive Bandaids were removed. Graft survival was assessed daily and rejection was defined as greater than $80 \%$ of the skin becoming necrotic.

\section{Splenocyte isolation}

Spleens were homogenized in hypotonic ammonium chloride potassium (ACK) lysis buffer for 5 minutes to lyse red blood cells. Cells were resuspended in Dulbecco's Modified Eagle Medium (DMEM, Invitrogen) supplemented with 5\% fetal bovine serum (FBS; HyClone, Logan, $\mathrm{UT})$, penicillin $(100 \mathrm{U} / \mathrm{mL})$, streptomycin $(100 \mu \mathrm{g} / \mathrm{mL})$, HEPES buffer $(50 \mu \mathrm{M}), \beta$-mercaptoethanol $(50 \mu \mathrm{M})$, and non-essential amino acids (1\% final volume) (complete DMEM). Cells were filtered through cell strainers, centrifuged, and resuspended in complete DMEM. Live cells were counted with the Countess Automated Cell Counter (Invitrogen), using the trypan blue exclusion method.

\section{T cell enrichment}

$\mathrm{CD}^{+} \mathrm{T}$ cells were enriched by negative selection using magnetic beads according to the instructions of the manufacturer (Stem Cell, Vancouver, Canada). Purity of $\mathrm{T}$ cells was verified in each experiment to be equal or superior to $85 \%$.

\section{Flow cytometry and pentamer staining}

Flow cytometric analyses were performed on single-cell suspensions stained in FACS buffer (PBS, 1\% BSA, and $0.01 \% \mathrm{NaN}_{3}$ ). Cells were then washed, resuspended in FACS buffer, and immediately analyzed by flow cytometry. Biotinylated pentamers of $\mathrm{K}^{\mathrm{b}}$ complexed to SIY peptide (ProImmune, Oxford, U.K.) were used according to the manufacturer's protocol and coupled to streptavidinPE. Cells were labeled with PE-, PE-Cy7-, APC-, APC-Cy7-, or FITC- conjugated antibodies. The antibodies used targeted murine $\mathrm{CD} 4, \mathrm{CD} 8 \alpha$ or $\mathrm{CD} 8 \beta$, $\mathrm{B} 220$, or CD44. These antibodies were obtained from BD Biosciences (San Jose, CA), eBioscience (San Diego, CA), or Biolegend (San Diego, CA). In certain experiments, cells were stained with 7-AAD obtained from Invitrogen (Carlsbad, CA). For proliferation assays, cells were permeabilized, fixed and stained with APC-conjugated Ki67 according to the manufacturer's instructions (BD Biosciences). Samples were acquired using Accuri, FACSCanto, or LSR Fortessa (BD Biosciences) flow cytometers. Data were analyzed using Flowjo software (TreeStar).

\section{ELISpot assay}

The mouse IFN- $\gamma E L I S p o t$ assay was conducted using the BD Bioscience (San Jose, CA) kit according to the manufacturer's protocol. ELISpot plates were coated with anti-mouse IFN- $\gamma$ antibody and stored overnight at $4{ }^{\circ} \mathrm{C}$. Plates were then washed and blocked with DMEM supplemented with 10\% FBS for 2 hours at room temperature. Splenocytes $\left(10^{6}\right.$ cells/well $)$ or enriched $\mathrm{CD}^{+} \mathrm{T}$ cells $\left(2 \times 10^{5}\right.$ cells/well $)$ were plated. Stimulation was performed with irradiated MC57-SIY tumor cells 
$(20,000 \mathrm{rad})$ or PMA $(50 \mathrm{ng} / \mathrm{ml})$ and ionomycin $(0.5 \mu \mathrm{g} /$ $\mathrm{ml}$ ) as a positive control. Plates were stored at $37^{\circ} \mathrm{C}$ in a $7.5 \% \mathrm{CO}_{2}$ incubator overnight, washed, and coated with detection antibody for 2 hours at room temperature. They were again washed and coated with avidin-peroxidase for 1 hour at room temperature. Plates were washed and developed by addition of 3-amino-9-ethylcarbazole (AEC) substrate. Developed plates were dried overnight, read using an ImmunoSpot Series 3 Analyzer, and analyzed with ImmunoSpot software.

\section{Cytokine bead array}

The mouse cytokine bead array was conducted using the Bio-Rad Laboratories Bio-Plex Pro ${ }^{\mathrm{Tm}}$ Mouse Cytokine Th17 Panel A 6-Plex Group (Hercules, CA) kit according to the manufacturer's protocol. Mice were challenged for 7 days with $10^{6}$ MC57-SIY tumor cells. CD8 ${ }^{+}$ $\mathrm{T}$ cells were then isolated and restimulated with irradiated tumor cells or PMA + ionomycin. Supernatants were collected, and cytokine concentration was assessed. In addition, supernatants from PMA + ionomycin-stimulated samples were serially diluted and analyzed for IFN$\gamma$ content by ELISA to ensure that oversaturation of the assay was not masking differences between the samples.

\section{Cytotoxicity assay}

Naïve syngeneic mice were sacrificed, and single-cell suspensions of whole splenocytes were prepared. T cells were depleted from splenocytes by negative selection for $\mathrm{CD}^{+}{ }^{+}$and $\mathrm{CD} 8^{+}$cells using magnetic beads according to the instructions of the manufacturer (Stem Cell, Vancouver, Canada). Half of the remaining splenocytes were incubated with SIY peptide at a concentration of $1 \mu \mathrm{M}$ at $37^{\circ} \mathrm{C}$ for one hour. All cells were washed. Peptide-loaded cells were stained with $0.5 \mu \mathrm{M}$ CFSE, and remaining splenocytes were stained with $5 \mu \mathrm{M}$ CFSE. Cells were counted using the Accuri flow cytometer, and equal populations of cells were intravenously transferred into tumorbearing mice one week post-tumor inoculation. The day after transfer, tumor-bearing mice were sacrificed, and populations of transferred cells were analyzed by flow cytometry. Specific lysis was calculated using the formula, \% Specific Lysis $=\left[r_{\text {experimental }} / r_{\text {naive }}\right] \times 100$ where $r=\frac{\% \text { CFSE } E^{l o} \text { cells }}{\% \text { CFSE }}$.

\section{Statistical analyses}

Comparisons of means were performed with GraphPad Prism (GraphPad Software) using the two-way ANOVA where appropriate with Bonferroni's correction for multiple comparisons. Where appropriate, comparisons of means were performed with InStat software using the $t$-test. Differences were considered significant for $\mathrm{p}$ values $<0.05$.

\section{Additional file}

Additional file 1: Figure S1. Stimulation with PMA + ionomycin elicits similar IFN- $\gamma$ production from control and IKK $\beta$-deficient $C D 8^{+} \mathrm{T}$ cells. Supernatants from Figure $3 c$ were serially diluted and the concentration of IFN- $\gamma$ was measured by ELISA.

\section{Competing interests}

The authors declare that they have no competing interests.

\section{Authors' contributions}

SEB participated in the design of the study and interpretation of data, carried out tumor growth experiments and functional assays, and performed statistical analyses. YW carried out the skin transplant experiments. LLM participated in the design and discussion of the experiments. TFG, CE and MA conceived the study, participated in its design and coordination, and edited the manuscript. All authors read and approved the final manuscript.

\section{Authors' information}

Cesar Evaristo and Maria-Luisa Alegre are co-last authors

\section{Acknowledgements}

The authors would like to acknowledge Michelle Miller for help with data interpretation, statistical analysis, and revision of the manuscript. We would also like to thank Drs. Michael Karin (UC San Diego), Alexander Chervonsky ( $U$ of Chicago) and Daniel Littman (NYU) for donating mice that were essential to the completion of this study. TFG was supported by RO1 CA127475 and a Team Science Award from the Melanoma Research Alliance. CE was supported by a T32 post-doctoral fellowship from the University of Chicago Committee on Cancer Biology and from Bolsa SFRH/BPD/80353/ 2011 from the Portuguese Fundaçao para a Ciencia e Tecnologia. MLA was supported by a pilot grant from the University of Chicago's Comprehensive Cancer Center and from NIH/NIAID RO1 Al052352. This work was also supported by Cancer Center Support Grant \#CA014599.

\section{Author details}

'Department of Medicine, The University of Chicago, 924 E. 57th St. JFK-R312, Chicago, IL 60637, USA. ${ }^{2}$ Department of Pathology, The University of Chicago, 927 E. 57th St, Chicago, IL 60637, USA. ${ }^{3}$ Genentech, Inc., 1 DNA Way MS: 245c, South San Francisco, CA 94080, USA.

Received: 7 October 2014 Accepted: 3 December 2014

Published online: 20 January 2015

\section{References}

1. Coulie PG, Van den Eynde BJ, van der Bruggen $\mathrm{P}$, Boon T: Tumour antigens recognized by $T$ lymphocytes: at the core of cancer immunotherapy. Nat Rev Cancer 2014, 14(2):135-146.

2. Chakraborty AK, Weiss A: Insights into the initiation of TCR signaling. Nat Immunol 2014, 15(9):798-807.

3. Abe BT, Shin DS, Mocholi E, Macian F: NFAT1 supports tumor-induced anergy of CD4(+) T cells. Cancer Res 2012, 72(18):4642-4651.

4. Chow CW, Rincon M, Davis RJ: Requirement for transcription factor NFAT in interleukin-2 expression. Mol Cell Biol 1999, 19(3):2300-2307.

5. Xiao G, Deng A, Liu H, Ge G, Liu X: Activator protein 1 suppresses antitumor T-cell function via the induction of programmed death 1. Proc Natl Acad Sci U S A 2012, 109(38):15419-15424.

6. Uzzo RG, Rayman P, Kolenko V, Clark PE, Cathcart MK, Bloom T, Novick AC, Bukowski RM, Hamilton T, Finke JH: Renal cell carcinoma-derived gangliosides suppress nuclear factor-kappaB activation in T cells. J Clin Invest 1999, 104(6):769-776.

7. Broderick L, Brooks SP, Takita H, Baer AN, Bernstein JM, Bankert RB: IL-12 reverses anergy to $T$ cell receptor triggering in human lung tumor-associated memory T cells. Clin Immunol 2006, 118(2-3):159-169.

8. Simpson-Abelson MR, Loyall JL, Lehman HK, Barnas JL, Minderman H, O'Loughlin KL, Wallace PK, George TC, Peng P, Kelleher RJ Jr, Odunsi K, Bankert RB: Human ovarian tumor ascites fluids rapidly and reversibly inhibit T cell receptor-induced NF-kappaB and NFAT signaling in tumor-associated T cells. Cancer Immun 2013, 13:14 
9. Correa MR, Ochoa AC, Ghosh P, Mizoguchi H, Harvey L, Longo DL: Sequential development of structural and functional alterations in T cells from tumor-bearing mice. J Immunol 1997, 158(11):5292-5296.

10. Ghosh P, Sica A, Young HA, Ye J, Franco JL, Wiltrout RH, Longo DL, Rice NR, Komschlies KL: Alterations in NF kappa B/Rel family proteins in splenic T-cells from tumor-bearing mice and reversal following therapy. Cancer Res 1994, 54(11):2969-2972.

11. Bonizzi G, Karin M: The two NF-kappaB activation pathways and their role in innate and adaptive immunity. Trends Immunol 2004, 25(6):280-288.

12. Roche MI, Ramadas RA, Medoff BD: The role of CARMA1 in T cells. Crit Rev Immunol 2013, 33(3):219-243

13. Boothby MR, Mora AL, Scherer DC, Brockman JA, Ballard DW: Perturbation of the T lymphocyte lineage in transgenic mice expressing a constitutive repressor of nuclear factor (NF)-kappaB. J Exp Med 1997, 185:1897-1907.

14. Schmidt-Supprian M, Courtois G, Tian J, Coyle AJ, Israel A, Rajewsky K, Pasparakis M: Mature T cells depend on signaling through the IKK complex. Immunity 2003, 19(3):377-389.

15. Jun JE, Wilson LE, Vinuesa CG, Lesage S, Blery M, Miosge LA, Cook MC, Kucharska EM, Hara H, Penninger JM, Domashenz H, Hong NA, Glynne RJK, Nelms KA, Goodnow CC: Identifying the MAGUK protein Carma-1 as a central regulator of humoral immune responses and atopy by genome-wide mouse mutagenesis. Immunity 2003, 18(6):751-762.

16. Egawa T, Albrecht B, Favier B, Sunshine MJ, Mirchandani K, O'Brien W, Thome M, Littman DR: Requirement for CARMA1 in antigen receptor-induced NF-kappa $B$ activation and lymphocyte proliferation. Curr Biol 2003, 13(14):1252-1258.

17. Hara H, Wada T, Bakal C, Kozieradzki I, Suzuki S, Suzuki N, Nghiem M, Griffiths EK, Krawczyk C, Bauer B, D'Acquisto F, Ghosh S, Yeh WC, Baier G, Rottapel R, Penninger JM: The MAGUK family protein CARD11 is essential for lymphocyte activation. Immunity 2003, 18(6):763-775.

18. Aronica MA, Mora AL, Mitchell DB, Finn PW, Johnson JE, Sheller JR, Boothby MR: Preferential role for NF-kappa B/Rel signaling in the type 1 but not type 2 T cell-dependent immune response in vivo. J Immunol 1999, 163(9):5116-5124.

19. Mora A, Youn J, Keegan A, Boothby M: NF-kappa B/Rel participation in the lymphokine-dependent proliferation of T Iymphoid cells. J Immunol 2001, 166(4):2218-2227

20. Mora AL, Corn RA, Stanic AK, Goenka S, Aronica M, Stanley S, Ballard DW Joyce S, Boothby M: Antiapoptotic function of NF-kappaB in T lymphocytes is influenced by their differentiation status: roles of Fas, c-FLIP, and Bcl-xL. Cell Death Differ 2003, 10(9):1032-1044.

21. Molinero LL, Cubre A, Mora-Solano C, Wang Y, Alegre ML: T cell receptor/CARMA1/NF-kappaB signaling controls T-helper (Th) 17 differentiation. Proc Natl Acad Sci U S A 2012, 109(45):18529-18534

22. Stanic AK, Bezbradica JS, Park JJ, Matsuki N, Mora AL, Van Kaer L, Boothby MR, Joyce S: NF-kappaB controls cell fate specification, survival, and molecular differentiation of immunoregulatory natural T lymphocytes. $\mathrm{J}$ Immunol 2004, 172(4):2265-2273.

23. Molinero LL, Yang J, Gajewski T, Abraham C, Farrar MA, Alegre ML: CARMA1 controls an early checkpoint in the thymic development of FoxP3+ regulatory T cells. J Immunol 2009, 182(11):6736-6743.

24. Barnes MJ, Krebs P, Harris N, Eidenschenk C, Gonzalez-Quintial R, Arnold CN, Crozat K, Sovath S, Moresco EM, Theofilopoulos AN, Beutler B, Hoebe K: Commitment to the Regulatory T Cell Lineage Requires CARMA1 in the Thymus but Not in the Periphery. PLoS Biol 2009, 7(3):e51.

25. Isomura I, Palmer S, Grumont RJ, Bunting K, Hoyne G, Wilkinson N, Banerjee A, Proietto A, Gugasyan R, Wu L, McNally A, Steptoe RJ, Thomas R, Shannon MF, Gerondakis S: c-Rel is required for the development of thymic Foxp3+ CD4 regulatory T cells. J Exp Med 2009, 206(13):3001-3014.

26. Ruan Q, Kameswaran V, Tone Y, Li L, Liou HC, Greene MI, Tone M, Chen YH: Development of Foxp3(+) regulatory $t$ cells is driven by the c-Rel enhanceosome. Immunity 2009, 31(6):932-940.

27. Visekruna A, Huber M, Hellhund A, Bothur E, Reinhard K, Bollig N, Schmidt N, Joeris T, Lohoff M, Steinhoff U: c-Rel is crucial for the induction of Foxp3(+) regulatory CD4(+) T cells but not $\mathrm{T}(\mathrm{H}) 17$ cells. Eur J Immunol 2010, 40(3):671-676.

28. Molinero LL, Miller ML, Evaristo C, Alegre ML: High TCR stimuli prevent induced regulatory $T$ cell differentiation in a NF-kappaB-dependent manner. J Immunol 2011, 186(8):4609-4617.

29. Zhou P, Hwang KW, Palucki DA, Guo Z, Boothby M, Newell KA, Alegre ML: Impaired NF-kB activation in T cells permits tolerance to primary heart allografts and to secondary donor skin grafts. Amer J Transplant 2003, 3:139-147.

30. Porras DL, Wang Y, Zhou P, Molinero LL, Alegre ML: Role of T-cell-specific nuclear factor kappaB in islet allograft rejection. Transplantation 2012, 93(10):976-982.

31. Schmidt-Supprian M, Tian J, Ji H, Terhorst C, Bhan AK, Grant EP, Pasparakis M, Casola S, Coyle AJ, Rajewsky K: I kappa B kinase 2 deficiency in T cells leads to defects in priming, B cell help, germinal center reactions, and homeostatic expansion. J Immuno/ 2004, 173(3):1612-1619.

32. Silva A, Cornish G, Ley SC, Seddon B: NF-kappaB signaling mediates homeostatic maturation of new T cells. Proc Natl Acad Sci U S A 2014, 111(9):E846-E855.

33. Spiotto MT, Yu P, Rowley DA, Nishimura MI, Meredith SC, Gajewski TF, Fu $Y X$, Schreiber $H$ : Increasing tumor antigen expression overcomes "ignorance" to solid tumors via crosspresentation by bone marrow-derived stromal cells. Immunity 2002, 17(6):737-747.

34. Kawai T, Akira S: Signaling to NF-kappaB by Toll-like receptors. Trends Mol Med 2007, 13(11):460-469.

35. Prasad S, Ravindran J, Aggarwal BB: NF-kappaB and cancer: how intimate is this relationship. Mol Cell Biochem 2010, 336(1-2):25-37.

36. Vilimas T, Mascarenhas J, Palomero T, Mandal M, Buonamici S, Meng F Thompson B, Spaulding C, Macaroun S, Alegre ML, Kee BL, Ferrando A, Miele L, Aifantis I: Targeting the NF-kappaB signaling pathway in Notch1-induced T-cell leukemia. Nat Med 2007, 13(1):70-77.

37. Hopewell EL, Zhao W, Fulp WJ, Bronk CC, Lopez AS, Massengill M, Antonia S, Celis E, Haura EB, Enkemann SA, Chen DT, Beg AA: Lung tumor NF-kappaB signaling promotes T cell-mediated immune surveillance. J Clin Invest 2013, 123(6):2509-2522.

38. Schmid JA, Birbach A: IkappaB kinase beta (IKKbeta/IKK2/IKBKB)-a key molecule in signaling to the transcription factor NF-kappaB. Cytokine Growth Factor Rev 2008, 19(2):157-165

39. Blonska M, Pappu BP, Matsumoto R, Li H, Su B, Wang D, Lin X: The CARMA1-Bcl10 signaling complex selectively regulates JNK2 kinase in the T cell receptor-signaling pathway. Immunity 2007, 26(1):55-66.

40. Gerondakis S, Fulford TS, Messina NL, Grumont RJ: NF-kappaB control of T cell development. Nat Immunol 2014, 15(1):15-25.

41. Huang C, Bi E, Hu Y, Deng W, Tian Z, Dong C, Hu Y, Sun B: A novel NF-kappaB binding site controls human granzyme $B$ gene transcription. $\mathrm{J}$ Immunol 2006, 176(7):4173-4181.

42. Sica A, Tan $T H$, Rice $N$, Kretzschmar M, Ghosh P, Young HA: The c-rel protooncogene product c-Rel but not NF-kappa B binds to the intronic region of the human interferon-gamma gene at a site related to an interferon-stimulable response element. Proc Natl Acad Sci U S A 1992, 89(5):1740-1744

43. Kline J, Zhang L, Battaglia L, Cohen KS, Gajewski TF: Cellular and molecular requirements for rejection of B16 melanoma in the setting of regulatory T cell depletion and homeostatic proliferation. J Immunol 2012. 188(6):2630-2642.

44. Mortenson ED, Park S, Jiang Z, Wang S, Fu YX: Effective anti-neu-initiated antitumor responses require the complex role of CD4+ T cells. Clin Cancer Res 2013, 19(6):1476-1486.

45. Thiery J, Lieberman J: Perforin: a key pore-forming protein for immune control of viruses and cancer. Subcell Biochem 2014, 80:197-220.

46. Fields PE, Gajewski TF, Fitch FW: Blocked Ras activation in anergic CD4+ T cells. Science 1996, 271:1276-1278.

47. Knudson KM, Hamilton SE, Daniels MA, Jameson SC, Teixeiro E: Cutting edge: The signals for the generation of $\mathrm{T}$ cell memory are qualitatively different depending on TCR ligand strength. J Immunol 2013, 191(12):5797-5801

48. Finn PW, Stone JR, Boothby MR, Perkins DL: Inhibition of NF-kappaB-dependent T cell activation abrogates acute allograft rejection. $J$ Immuno/ 2001, 167(10):5994-6001.

49. Molinero L, Zhou P, Wang Y, Harlin H, Cosmano J, Yokota Y, Kee B, Abraham C, Alegre ML: Epidermal Langerhans cells play a major role in skin allograft rejection in mice with NF-kB-impaired T cells. Am J Transplant 2008, 8:21-31.

50. Molinero LL, Alegre ML: Role of T cell-nuclear factor kappaB in transplantation. Transplant Rev 2011, 26(3):189-200.

51. Alegre ML, Najafian $\mathrm{N}$ : Costimulatory molecules as targets for the induction of transplantation tolerance. Curr Mol Med 2006, 6(8):843-857.

52. Arch $\mathrm{RH}$, Thompson $\mathrm{CB}: 4-1 \mathrm{BB}$ and $\mathrm{O} \times 40$ are members of a tumor necrosis factor (TNF)-nerve growth factor receptor subfamily that bind 
TNF receptor-associated factors and activate nuclear factor kappaB. Mol Cell Biol 1998, 18(1):558-565.

53. Young Lee S, Yull Lee S, Kandala G, Liou M, Liou H, Choi Y: CD30/TNF receptor-associated factor interaction: NF-kB activation and binding specificity. Proc Natl Acad Sci USA 1996, 93(18):9699-9703.

54. Martinez-Forero I, Azpilikueta A, Bolanos-Mateo E, Nistal-Villan E, Palazon A Teijeira A, Perez-Chacon G, Morales-Kastresana A, Murillo O, Jure-Kunkel M, Zapata JM, Melero I: T cell costimulation with anti-CD137 monoclonal antibodies is mediated by K63-polyubiquitin-dependent signals from endosomes. J Immunol 2013, 190(12):6694-6706.

55. Dunn GP, Old L, Schreiber RD: The immunobiology of cancer immunosurveillance and immunoediting. Immunity 2004, 21(2):137-148.

56. Harlin $\mathrm{H}$, Hwang KW, Palucki DA, Kim O, Thompson CB, Boothby M, Alegre ML: CTLA-4 engagement regulates NF-kappaB activation in vivo. Eur I Immunol 2002, 32(8):2095-2104.

57. Qiao G, Li Z, Molinero L, Alegre ML, Ying H, Sun Z, Penninger JM, Zhang J: T-cell receptor-induced NF-kappaB activation is negatively regulated by E3 ubiquitin ligase Cbl-b. Mol Cell Biol 2008, 28(7):2470-2480.

58. Lee PP, Fitzpatrick DR, Beard C, Jessup HK, Lehar S, Makar KW, PerezMelgosa M, Sweetser MT, Schlissel MS, Nguyen S, Cherry SR, Tsai JK, Tucker SM, Weaver WM, Kelso A, Jaenisch R, Wilson CB: A critical role for Dnmt1 and DNA methylation in T cell development, function, and survival. Immunity 2001, 15(5):763-774.

59. Orban PC, Chui D, Marth JD: Tissue- and site-specific DNA recombination in transgenic mice. Proc Natl Acad Sci U S A 1992, 89(15):6861-6865.

60. Pasparakis M, Courtois G, Hafner M, Schmidt-Supprian M, Nenci A, Toksoy A, Krampert M, Goebeler M, Gillitzer R, Israel A, Krieg T, Rajewsky K, Haase I: TNF-mediated inflammatory skin disease in mice with epidermis-specific deletion of IKK2. Nature 2002, 417(6891):861-866.

61. Adachi O, Kawai T, Takeda K, Matsumoto M, Tsutsui H, Sakagami M, Nakanishi K, Akira S: Targeted disruption of the MyD88 gene results in loss of IL-1- and IL-18-mediated function. Immunity 1998, 9(1):143-150.

\section{Submit your next manuscript to BioMed Central and take full advantage of:}

- Convenient online submission

- Thorough peer review

- No space constraints or color figure charges

- Immediate publication on acceptance

- Inclusion in PubMed, CAS, Scopus and Google Scholar

- Research which is freely available for redistribution 